\title{
What's New in the Pathophysiology of Sickle Cell Disease?
}

\author{
Adekunle D. Adekile \\ Department of Pediatrics, Faculty of Medicine, Health Sciences Centre, Kuwait University, Jabriya, Kuwait
}

Hemoglobin $\mathrm{S}(\mathrm{Hb} \mathrm{S})$ is the most widely distributed structural hemoglobin $(\mathrm{Hb})$ variant and results from the substitution of valine for glutamic acid in the 6th amino acid in the $\beta$-globin chain. This leads to reduced solubility of the $\mathrm{Hb}$ molecule especially in a deoxygenated medium with the formation of polymers, which distort the red blood cell (RBC) membrane causing rigidity and less deformability of the cell. In addition, there is reduced life span of the RBC. Homozygotes or compound heterozygotes ( $\mathrm{S} \beta^{0}$ thal, $\mathrm{SC}$, etc.) have sickle cell disease (SCD), which is characterized by recurrent vaso-occlusion with consequent body pains, chronic hemolysis and end-organ damage.

Considerable knowledge has been accumulated about the molecular characteristics of the disease. Several linkage disequilibrium refraction fragment length polymorphisms in the $\beta$-globin gene cluster define the four major haplotypes associated with the $\beta^{S}$ locus [1]. These are the Benin, Senegal, Bantu and Arab-Indian haplotypes. Clinical research has demonstrated the influence of haplotypes on the phenotype such that Senegal and Arabian/Indian haplotypes are associated with the mildest course. Patients with these two haplotypes have elevated $\mathrm{Hb} F$, which has also been shown to, independently, ameliorate clinical course because it improves solubility of the $\mathrm{Hb} \mathrm{S}$ molecule, reduces polymerization and anemia [2].

\begin{tabular}{ll}
\hline KARGER & $\begin{array}{l}\text { ( } 2013 \text { S. Karger AG, Basel } \\
1011-7571 / 13 / 0224-0311 \$ 38.00 / 0\end{array}$ \\
E-Mail karger@karger.com & $\begin{array}{l}\text { This is an Open Access article licensed under the terms of the } \\
\text { www.karger.com/mpp }\end{array}$ \\
$\begin{array}{l}\text { Creative Commons Attribution-NonCommercial 3.0 Un- } \\
\text { ported license (CC BY-NC) (www.karger.com/OA-license), } \\
\text { applicable to the online version of the article only. Distribu- } \\
\text { tion permitted for non-commercial purposes only. }\end{array}$
\end{tabular}

Efforts to elucidate the pathophysiology of the disease in the 1980s culminated in a detailed description of the kinetics of gelation, outlining the factors which promote $\mathrm{Hb} \mathrm{S}$ polymerization. Essentially, with deoxygenation there is a critical delay time before polymerization commences with an initial nucleus followed by rapid extension [3]. This delay time of gelation is inversely proportional to about the 30 th power of the deoxy-Hb S concentration within the RBC. Significant rheological changes ensue with increased viscosity, which promotes vaso-occlusion and thrombotic phenomena. Moreover, if the transit time from the venous end of the capillary bed to the arterial side is shorter than the delay time of gelation, polymerization and vascular occlusion would be avoided. Several other factors including $\mathrm{pH}, \mathrm{O}_{2}$ tension, temperature and the RBC 2,3-diphosphoglycerate levels all influence the rate of gelation with implications for potential therapeutic interventions [4].

In recent years, two major phenotypes of SCD have been recognized: recurrent vaso-occlusion on one end and hemolysis on the other. While the different models of gelation and rheological abnormalities would explain the former, they do not adequately explain the chronic vasculopathy that is the hallmark of the disorder. It is now recognized that SCD is a chronic inflammatory state with extensive oxidative stress involving several enzyme systems and isch- 
emia/reperfusion injury, with nitric oxide (NO) dysregulation playing a central role. Another model of SCD pathophysiology has therefore been proposed that involves the interaction of hemolysis and the endothelium [5].

While $\mathrm{Hb}$ is safely packaged within the plasma membrane of the RBC, its release, following hemolysis, sets off an intense inflammatory response with eventual $\mathrm{NO}$ depletion. NO is a critical endogenous vasodilator synthesized by endothelial cells from its obligate substrate L-arginine, which is converted to citrulline by NO synthases. SCD is characterized by a state of NO resistance, inactivation and impaired availability with consequent vasoconstriction, platelet activation, up-regulation of adhesion molecules, thrombin generation and endothelial intima proliferation culminating in arterial stenosis and eventual occlusion, with dire consequences [6, 7]. The release of arginase from the lysed RBCs reduces available arginine by redirecting its metabolism to ornithine (instead of citrulline and NO), with the formation of polyamines and proline, which promote smooth muscle proliferation and collagen synthesis [8]. The subphenotypes of SCD which are directly attributable to hemolysis and endothe- lial dysfunction include pulmonary hypertension, stroke, priapism and leg ulcers. The biomarkers of this process include free plasma hemoglobin, arginase, reticulocyte count, serum lactate dehydrogenase and bilirubin. The risk of pulmonary hypertension, i.e. a tricuspid regurgitant velocity of $\geq 2.5 \mathrm{~m} / \mathrm{s}$, is currently the strongest predictor of early death in adult SCD patients [9].

One hallmark of SCD is its clinical variability and given the complexity of its pathophysiology and the various inflammatory and other pathways involved, it is not surprising that many other genetic factors modify the course of the disease. While $\mathrm{Hb} \mathrm{F}$ and a coexistent $\alpha$-thal trait are recognized as the major ameliorating factors, several single nucleotide polymorphisms in gene loci both within the $\beta$-globin gene cluster on chromosome 11 and in other chromosomes are being increasingly identified, especially with recent genome-wide association studies, to be important modifiers [10]. However, it does not appear that these genetic mechanisms adequately explain the phenotypic diversity of the disease. Epigenetic and environmental mechanisms are quite important and deserve further coordinated studies.

\section{References}

$>1$ Nagel RL, Ranney HM: Genetic epidemiology of the $\beta$-globin gene. Semin Hematol 1990;27: 332-349.

2 Powars DR, Weiss JN, Chan IS, et al: Is here a threshold level of fetal hemoglobin that ameliorates morbidity of sickle cell anemia? Blood 1984;63:921-926.

$>3$ Eaton WR, Hofrichter J: Hemoglobin S gelation and sickle cell disease. Blood 1987;70: 1245-1266.

-4 San Biagio PL, Hofrichter J, Mozzarelli A, et al: Current perspectives on the kinetics of hemoglobin S gelation. Ann NY Acad Sci 1989; 565:53-62.
5 Kato GJ, Hebbel RP, Steinberg MH, et al: Vasculopathy in sickle cell disease: biology, pathophysiology, genetics, translational medicine, and new research directions. Am J Hematol 2009;84:618-625.

6 Morris CR: Mechanisms of vasculopathy in sickle cell disease and thalassemia. Hematology Am Soc Hematology Educ Program 2008; 177-185.
7 Morris CR: Vascular risk assessment in patients with sickle cell disease. Haematologica 2011;96:1-5.

-8 Durante W, Johnson FK, Johnson RA: Arginase: a critical regulator of nitric oxide synthesis and vascular function. Clin Exp Pharmacol Physiol 2007;34:906-911.

$>9$ Gladwin MT, Sachdev V, Jison M, et al: Pulmonary hypertension as a risk factor for death in patients with sickle cell disease. N Engl J Med 2004;350:886-895.

10 Steinberg MH, Sebastiani P: Genetic modifiers of sickle cell disease. Am J Hematol 2012; 87:795-803. 